\title{
Diversity decoupled from ecosystem function and resilience during mass extinction recovery
}

Authors: Sarah A. Alvarez ${ }^{1,2, \dagger^{*}}$, Samantha J. Gibbs ${ }^{3}$, Paul R. Bown ${ }^{2}$, Hojung Kim² ${ }^{2}$, Rosie M. Sheward ${ }^{4}$, Andy Ridgwell ${ }^{5}$.

\author{
Affiliations: \\ ${ }^{1}$ School of Geographical Sciences, University of Bristol, University Road, Bristol, BS8 1SS, \\ UK. \\ ${ }^{2}$ Department of Earth Sciences, University College London, Gower Street, London, WC1E \\ 6BT, UK. \\ ${ }^{3}$ Ocean and Earth Science, National Oceanography Centre, Southampton, University of \\ Southampton, Southampton, SO14 3ZH, UK. \\ ${ }^{4}$ Institute for Geoscience, Goethe-Universität Frankfurt, Altenhöferallee 1, 60438 Frankfurt \\ am Main, Germany. \\ ${ }^{5}$ Department of Earth Sciences, University of California at Riverside, Riverside, California \\ 92521, USA. \\ *Correspondence to: sarah.alvarez@ unigib.edu.gi \\ $\uparrow$ Current address: University of Gibraltar, Europa Point Campus, Gibraltar GX11 1AA.
}

The Chixulub bolide impact 66 million years ago drove near-instantaneous oceanic ecosystem collapse. Devastating diversity loss at the base of ocean food-webs likely triggered cascading extinctions across all trophic levels ${ }^{1-3}$ and caused severe disruption of ocean biogeochemical function, especially the cycling of carbon between the surface and deep sea ${ }^{4,5}$. The absence of sufficiently detailed biotic data spanning the postextinction interval has limited our understanding of how ecosystem resilience and biochemical function was restored, with estimates of 'recovery' varying from $<100$ years to 10 million years ${ }^{6-8}$. Using a 13-million-year long nannoplankton time-series we show that post-extinction communities exhibited 1.8 million years of exceptional volatility before a more stable equilibrium community emerged displaying hallmarks of resilience. The transition to this new equilibrium-state community with a broader cellsize spectrum coincides with indicators of carbon cycle restoration and a fully functioning biological pump ${ }^{9}$. This finding implies a fundamental link between ecosystem recovery and biogeochemical cycling over timescales that are longer than those suggested by proxies of export production ${ }^{7,8}$ but far shorter than the return of taxic richness ${ }^{6}$. That species richness remained low as both community stability and biological pump efficiency re-emerged, suggests that ecological function rather than number of species is more critical to community resilience and biochemical function.

The end Cretaceous bolide impact stripped the ocean of diversity and biogeochemical function ${ }^{1}$ more abruptly than any other mass extinction event, including the current anthropogenically-induced crisis. Following $>90 \%$ species extinction in calcifying plankton ${ }^{3}$, the immediate aftermath of the impact saw oceans repopulated by aberrant communities dominated by ephemeral species, atypical in ecology, physiology and cell size ${ }^{9-11}$. Over time a diverse, biochemically-functioning and resilient ecosystem was re-established. This wholesale re-assembly of the ocean ecosystem provides clues to the essential attributes that 
underpin stable ecosystems and maintain robust ecological states and function ${ }^{12,13}$. However, assessments of when this ecosystem 'recovery' was achieved vary widely in definition and duration. Export production proxies imply virtually instantaneous restoration of at least some biogeochemical functionality $(<100 \text { years })^{7,8}$, while the return of species richness to preextinction levels suggests recovery 8-10 million years (Myr) later ${ }^{6}$. Here, we track the postextinction path to ecosystem restoration by building an exceptional, high-resolution 13million-year community record of calcareous nannoplankton, the dominant fossil-forming primary producers. Much of the marine food-web leaves little or no fossil remains, but the biomineralised exoskeletons of calcareous nannoplankton provide a remarkable proxy for basal ecosystem health during past environmental change events (see ref. 3 and refs therein). Our new nannoplankton record bridges the temporal range of current recovery estimates and allows us to target measures of community stability (the level of deviation around the average state, see Methods) and resilience (the ability to resist and recover from perturbation ${ }^{14}$ ) as they re-emerged. The record from Ocean Drilling Program (ODP) Site 1209 in the Pacific Ocean (Extended Data Fig. 1, Methods) has highly-resolved orbital age control (see Methods) and complementary proxy data for environmental change and biogeochemical function. Our plankton data comprise a sample every 13 thousand years, spanning $13 \mathrm{Myr}$, with around 700,000 fossil counts providing an unprecedented time-series of key community parameters, including abundance, diversity, taxic richness, variance, dissimilarity and body size (see Methods).

Our data and analyses reveal striking temporal trends in nannoplankton community structure and resilience (Fig. 1). Most visually obvious is the differentiation of a highly volatile postextinction interval of $\sim 1.8 \mathrm{Myr}$, from a subsequent more 'stable' background state (Fig. 1e), conspicuous in the Summed Coefficient of Variation metric $\left(\Sigma_{\mathrm{CV}}\right)$. We primarily focus on this metric which quantifies the level of variance or 'stability' in relative abundances (see Methods) but as community stability is a multi-faceted concept, we also refer to other indices including community dissimilarity (Bray-Curtis Dissimilarity) and diversity (Simpson's index of dominance/evenness). These measures of community structure all point to the stateshift 1.8 Myr post-impact (Fig. 1, Extended Data Fig. 2) and an early Danian interval characterized by exceptional fluctuations that are statistically distinct from the rest of the record (Extended Data Fig. 2), hereafter referred to as Regime 1 (66.0-64.2 Myr ago) and Regime 2 (64.1-53.0 Myr ago). When we compare $\Sigma_{\mathrm{CV}}$ with carbon isotope $\left(\delta^{13} \mathrm{C}\right)$ excursion magnitude, a proxy for environmental change (Fig. 2, see Methods), the two regimes show strikingly different relationships with environmental forcing. The earliest Danian (Regime 1) exhibits no relationship between $\Sigma_{\mathrm{CV}}$ and $\delta^{13} \mathrm{C}$ magnitude, with prolonged high-amplitude variance largely the statistical impact of a series of ocean-wide abundance acmes ${ }^{10,15,16}$ (Fig. 3a, b, Extended Data Figs 3, 4), occurring alongside very little apparent environmental perturbation (Fig. 1a, 2). This interval saw very short-term $(<<100 \mathrm{kyr})$ impact-related environmental changes ${ }^{17,18}$ (cooling over $<50$ years, ref 17 , and warming through $<100 \mathrm{kyr}$, ref 18), waning Deccan trap volcanism over $600 \mathrm{kyr}$ (e.g., ref. 19), and only two notable environmental change events - the lower-C29n and Dan-C2 hyperthermals - all occurring or ceasing well before the interval of high variance comes to an end. Therefore, the disconnect between community metrics and indicators of climate variability suggests that environmental changes were not driving and maintaining the high levels of biotic variability through this 1.8-million-year interval. In contrast, above this level (Regime 2), $\delta^{13} \mathrm{C}$ magnitude is a strong predictor of community variance $\left(\mathrm{R}^{2}=54 \%\right.$ on first differences, Fig. 2$)$ with the majority of data forming a 'background' grouping punctuated by variance peaks associated with hyperthermal events ${ }^{20}$ (highlighted in red in Figs 1a, c, Fig. 2). This indicates that by the late Danian, nannoplankton communities were fluctuating around some steady state and 
demonstrate indicators of resilience ${ }^{14}$, including proportionate responses to environmental perturbation (i.e., the significant linear trend between carbon isotope excursion and variance) and rapid recoveries following each event (return of variance to the background state within $<200$ kyrs of the excursion, Fig. 1c and ref 21).

Tantalisingly, the shift to more stable communities approximately 64.2 Myr ago (the end of Regime 1) also falls towards the top of the interval of biological pump recovery ${ }^{9}$ (Fig. $3 f$ ). Ocean biogeochemical function was profoundly disrupted by the end-Cretaceous mass extinction, most obviously through weakening of the biological pump ${ }^{2,5,9}$. The scale and duration of this productivity reduction is contentious, ranging from scenarios of a lifeless Strangelove Ocean to a partially functioning Living Ocean state ${ }^{4}$, but the long, multimillionyear delay in restoration of the biological pump is well established ${ }^{2,22}$, and indicated by both the gradual increase in vertical carbon isotope gradient to pre-extinction values ${ }^{9}$ and changing community structures of benthic primary-consumer communities (benthic foraminifera) ${ }^{23}$. Carbon isotope gradients finally returned to pre-extinction values by $\sim 77$ Myrs after the event $^{9}$ providing an upper limit on full recovery of the biological pump. This broad concurrence between biological pump restoration and the shift to a more stable plankton community background state (Fig. 3) provides strong evidence for an intrinsic link between biological recovery of the ecosystem and its calibre of biochemical functioning. We can augment this understanding of ecosystem recovery and efficient biological pumping by exploring the roles of the post-extinction taxonomic rebuild and rapid cell-size increases using new, high-resolution species richness data (Fig. 3d; see Methods) and reconstructions of nannoplankton community cell volume (Fig. 3e; see Methods).

Mean community cell volume and species richness exhibit pulsed patterns through the Danian, both showing rapid increases in the first half million years after the mass extinction, from initially extremely low species numbers and predominantly very small cells (Fig. 3d, e). Rapid diversification within Regime 1 saw the appearance of $>15$ species alongside a peak in cell volume around $300 \mathrm{kyr}$ after the extinction level dominated by cells of heavily calcified calcareous dinoflagellates. A second phase of cell-volume increase occurred as carbon export gradually returned to pre-extinction values, and was driven by both diversity and ecology, with relative abundance increases in existing large taxa (such as Coccolithus, Extended Data Fig. 3) and the addition of larger new species across all of the emerging clades (Fig 3d). Modern observations indicate that phytoplankton community size structure is a critical control on export flux and, further, that nannoplankton mineral ballasting significantly increases the transfer efficiency of carbon ${ }^{24-26}$. The shift to larger cells and ballast biominerals seen in our early Danian cell size record (Fig. 3e) would therefore have contributed to increased carbon export flux with stable, diverse communities delivering this flux more consistently through space and time, and supporting greater size diversity in the zooplankton ${ }^{26}$. The role of larger zooplankton and the production of fast-sinking faecal pellets in these evolving export pathways is more difficult to reconstruct due to poor fossil records. However, an indication of higher trophic level disruption is seen in the early Danian zooplanktonic foraminifera where low diversities, acme fluctuations and small body size are observed across similar timescales to the recovery of the biological pump ${ }^{11,27}$. Finally, a third phase of cell volume increase coincides with a major expansion of ecological diversity marked by the appearance of the first specialist oligotrophic nannoplankton since the mass extinction (Discoasterales; 3.5 Myr post-extinction; Figs 1b, 3a, d, e, Extended Data Fig. 4; ref 28) and re-introduction of photosymbiotic strategies in planktonic foraminifera $(\sim 2.5 \mathrm{Myr}$ post-extinction; Fig. 3f; ref 9). Diversification then continued, with species richness only reaching pre-extinction levels at $10 \mathrm{Myr}$ after the mass extinction ( 56 Myr ago; Fig. 1g). 
The scale of ecosystem collapse at the $\mathrm{K} / \mathrm{Pg}$ event and protracted recovery of resilience, diversity and biogeochemical function, demonstrates the singular consequences of massextinction-level change and subsequent durability of ecosystems following restoration. Predictions of contemporary mass-extinction ${ }^{29}$ detail accelerating declines in ecosystem functioning as diversity falls $\mathrm{s}^{30,31}$. We show here that this relationship also holds in reverse as biodiversity reboots after a mass extinction. Early but modest taxic and trait (especially size) diversification within the recovering biota re-established ecosystem stability with links to functioning (specifically the biological pump) long before species richness and ecological diversity returned to pre-extinction levels. Rapid biotic turnover and community instability during this reboot increased the probability of biotically-forced evolution alighting on organisms capable of fulfilling essential functional roles, which in turn facilitated community recovery and the re-emergence of ecosystem stability. Ecosystem stability is therefore not determined by sheer numbers of species, but rather through the establishment and/or retention of key functional taxa fulfilling vital ecological and/or biogeochemical roles.

\section{References:}

1. Schulte, P. et al. The Chicxulub asteroid impact and mass extinction at the CretaceousPaleogene boundary. Science. 327, 1214-1218 (2010).

2. Coxall, H. K., D'Hondt, S. \& Zachos, J. C. Pelagic evolution and environmental recovery after the Cretaceous-Paleogene mass extinction. Geology 34, 297-300 (2006).

3. Bown, P. R., Lees, J. A. \& Young, J. R. Calcareous nannoplankton evolution and diversity through time. in Coccolithophores: from molecular processes to global impact (eds. Thierstein, H. R. \& Young, J. R.) 481-508 (Springer, 2004).

4. D'Hondt, S. Consequences of the Cretaceous/Paleogene mass extinction for marine ecosystems. Annu. Rev. Ecol. Evol. Syst. 36, 295-317 (2005).

5. Henehan, M. J., Hull, P. M., Penman, D. E., Rae, J. W. B. \& Schmidt, D. N. Biogeochemical significance of pelagic ecosystem function: an end-Cretaceous case study. Philos. Trans. R. Soc. B 371, 20150510 (2016).

6. Kirchner, J. W. \& Weil, A. Delayed biological recovery from extinctions throughout the fossil record. Nature 404, 177-180 (2000).

7. Sepúlveda, J., Wendler, J. E., Summons, Roger, E. \& Hinrichs, K.-U. Rapid Resurgence of Marine Productivity After the Cretaceous-Paleogene Mass Extinction. Science. 326, 129-132 (2009).

8. Alegret, L., Thomas, E. \& Lohmann, K. C. End-Cretaceous marine mass extinction not caused by productivity collapse. Proc. Natl. Acad. Sci. 109, 728-732 (2012).

9. Birch, H. S., Coxall, H. K., Pearson, P. N., Kroon, D. \& Schmidt, D. N. Partial collapse of the marine carbon pump after the Cretaceous-Paleogene boundary. Geology 44, 287-290 (2016).

10. Bown, P. Selective calcareous nannoplankton survivorship at the Cretaceous-Tertiary boundary. Geology 33, 653-656 (2005).

11. Gallala, N., Zaghbib-Turki, D., Arenillas, I., Arz, J. A. \& Molina, E. Catastrophic mass extinction and assemblage evolution in planktic foraminifera across the Cretaceous/Paleogene (K/Pg) boundary at Bidart (SW France). Mar. Micropaleontol. 
12. P. Hull, Life in the aftermath of mass extinctions. Curr. Biol., 25, R941-R952 (2015).

13. Barnosky, A. D, et al. Merging paleobiology with conservation biology to guide the

14. Hodgson, D., McDonald, J. L. \& Hosken, D. J. What do you mean, 'resilient'? Trends Ecol. Evol. 30, 503-506 (2015).

15. Varol, O. Palaeocene calcareous nannofossil biostratigraphy. in Nannofossils and their Applications (eds. Crux, J. A. \& van Heck, S. E.) 267-310 (Ellis Horwood, British Micropaleontological Society Series, 1989).

16. Pospichal, J. J. Calcareous nannoplankton mass extinction at the Cretaceous/Tertiary boundary: An update. in The Cretaceous-Tertiary Event and Other Catastrophes in Earth History. Geological Society of America Special Paper 307 (eds. Ryder, G., Fastovsky, D. E. \& Gartner, S.) 335-360 (1996).

17. Vellekoop, J. et al. Rapid short-term cooling following the Chicxulub impact at the Cretaceous-Paleogene boundary. Proc. Natl. Acad. Sci. 111, 7537-7541 (2014).

18. MacLeod, K. G., Quinton, P. C., Sepúlveda, J. \& Negra, M. H. Postimpact earliest Paleogene warming shown by fish debris oxygen isotopes (El Kef, Tunisia). Science. 360, 1467-1469 (2018).

19. Sprain, C. J. et al. The eruptive tempo of Deccan volcanism in relation to the Cretaceous-Paleogene boundary. Science 363, 866-870 (2019).

20. Zachos, J. C., McCarren, H., Murphy, B., Röhl, U. \& Westerhold, T. Tempo and scale of late Paleocene and early Eocene carbon isotope cycles: Implications for the origin of hyperthermals. Earth Planet. Sci. Lett. 299, 242-249 (2010).

21. Gibbs, S. J. et al. Scaled biotic disruption during early Eocene global warming events. Biogeosciences 9, 4679-4688 (2012).

22. Esmeray-Senlet, S. et al. Evidence for reduced export productivity following the Cretaceous/Paleogene mass extinction. Paleoceanography 10.1002/2014PA002724 (2015).

23. Alegret, L. \& Thomas, E. Deep-Sea environments across the Cretaceous/Paleogene boundary in the eastern South Atlantic Ocean (ODP Leg 208, Walvis Ridge). Mar. Micropaleontol. 64, 1-17 (2007).

24. Buesseler, K.O. \& Boyd, P.W. Shedding light on processes that control particle export and flux attenuation in the twilight zone of the open ocean. Limnol. Oceanogr. 54, 1210-1232 (2009).

25. Fischer, G. \& Karakaş G., Sinking rates and ballast composition of particles in the Atlantic Ocean: implications for the organic carbon fluxes to the deep ocean. Biogeosciences 6, 85-102 (2009).

26. Hansen, B., Bjørnsen, P., K. \& Hansen, P.J. et al. The size ratio between planktonic predators and their prey. Limnol. Oceanog. 39, 395-403 (1994).

27. Gerstel, J., Thunell, R. \& Ehrlich, R. Danian faunal succession : Planktonic foraminiferal response to a changing marine environment. Geology 15, 665-668 
(1987).

28. Fuqua, L. M., Bralower, T. J., Arthur, M. A. \& Patzkowsky, M. E. Evolution of calcareous nannoplankton and the recovery of marine food webs after the CretaceousPaleocene mass extinction. Palaios 23, 185-194 (2008).

29. Barnosky, A. D. et al. Has the Earth's sixth mass extinction already arrived? Nature 471, 51-57 (2011).

30. Cardinale, B. J. et al. Biodiversity loss and its impact on humanity. Nature 486, 59-67 (2012).

233 31. Reich, P. B. et al. Impacts of biodiversity loss escalate. Science. 336, 589-592 (2012).

32. Westerhold, T., Röhl, U., Donner, B. \& Zachos, J. C. Global extent of early Eocene hyperthermal events - a new Pacific benthic foraminiferal isotope record from Shatsky Rise (ODP Site 1209). Paleoceanogr. Paleoclimatology 33, 626-642 (2018). 
Figures:

Figure 1. Nannoplankton abundance, variability and diversity records from the latest Cretaceous to early Eocene. a, Carbon stable isotopes, dark green - benthic ${ }^{32}$, lighter green - bulk (see references in 21). b, Summary of main nannoplankton clade abundances determined for 981 samples. c, Summed coefficients of variation $\left(\Sigma_{\mathrm{CV}}\right)$ using $150 \mathrm{kyr}$ moving window (see Methods), separated into the early Danian (Regime 1, blue) and the rest of the record (Regime 2, grey and red). The Cretaceous to $\mathrm{K} / \mathrm{Pg}$ data points are in black. Triangles (colour-coded by regime, black for the $\mathrm{K} / \mathrm{Pg}$ window) show values for the named climate events, which for the Eocene hyperthermals were calculated across the event duration $(<150$ kyr). Event nomenclature follows references given in the Methods. The vertical black dashed line indicates estimated background level $\left(<2.5 \Sigma_{\mathrm{CV}}\right)$ based on the ranked order inflection point on (d) with above-'background' data highlighted in red in c. e, Ranked-order plot of Regime 1 datapoints where the dark red dashed line indicates an inflection point at the higher end of the $\Sigma_{\mathrm{CV}}$ values (marked on c). f, Calcareous nannoplankton species richness at $250 \mathrm{kyr}$ resolution (see Methods).

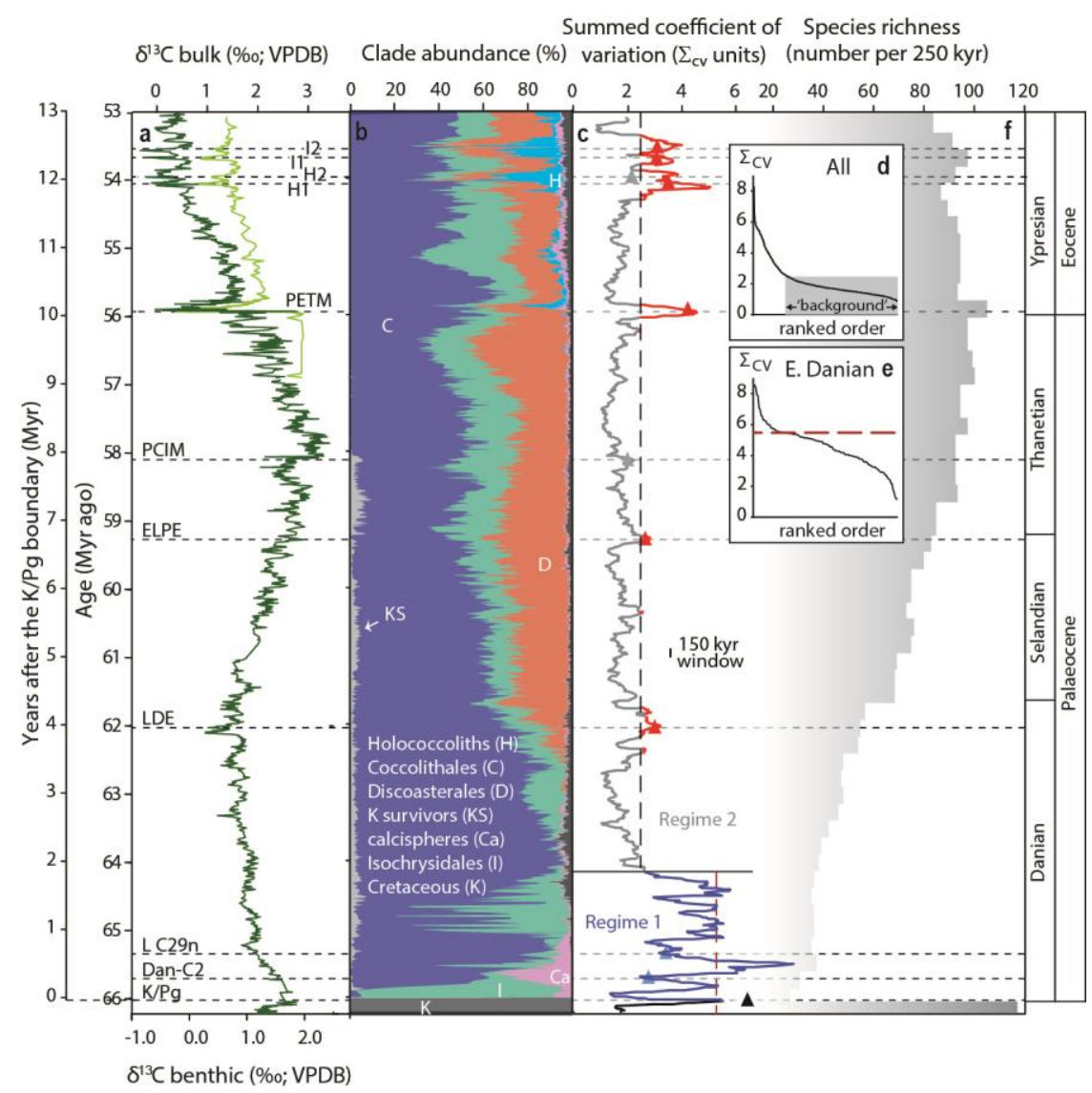


257 Figure 2. $\Sigma_{\mathrm{CV}}$ and magnitude of climate perturbation ( $\delta^{\mathbf{1 3}} \mathbf{C}$ excursion). a, raw data. $\mathbf{b}$,

258 first differences. The $\Sigma_{\mathrm{CV}}$ values are plotted for each named climate event (using the

259 highlighted values in Fig. 1c, here shown as triangles in a) and every intervening $150 \mathrm{kyr}$.

260 Data-points are separated into Cretaceous (black, $\mathrm{n}=2$, not included in b), early Danian

261 (blue, 66 to 64.2 Myr ago, Regime 1, $\mathrm{n}=23$ ) and the rest of the record (grey and above

262 background in red, Regime $2, \mathrm{n}=71$, from Fig. 1c, d). Regime $1 \Sigma_{\mathrm{CV}}$ shows no relationship with climatic perturbation (blue trend-line in b), unlike Regime 2 (generalised least squares trend-line for all grey plus red data-points, $n=71$, grey dashed line in $\mathbf{a}$ and $\mathbf{b}$ ), which is significant in both the raw data (a) and on first differences $(b)\left(\mathrm{R}^{2}=31 \%\right.$ and $52 \%$, respectively (see Methods). The inferred background level of 2.5, based on rank ordering (Fig. 1d), is indicated by the grey box.
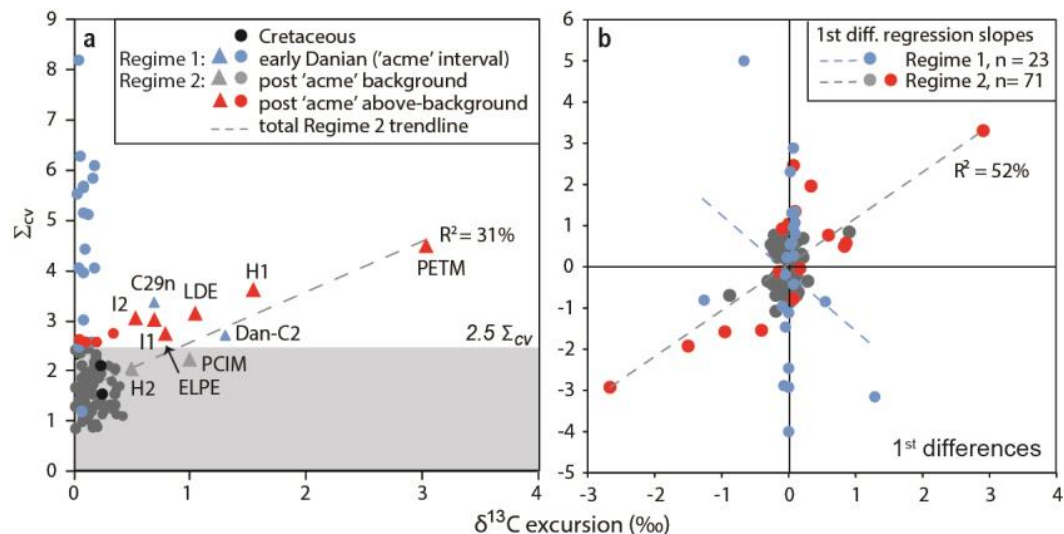
Figure 3. Danian nannoplankton community variance, acme abundances, diversity, cell volume and key milestones. a, Abundance records of the early Danian coccolithophore acmes and Discoasterales (Sphenolithus and Fasciculithus), b, $\Sigma_{\mathrm{CV}}$ (Regime 1 in blue, Regime 2 in grey and red) and Danian climate events. c, Community diversity (Simpson's index), 150 kyr moving average in grey. d, Global species richness resolved at $100 \mathrm{kyr}$ scale (see Methods). e, Estimated average (mean) cell volume and estimated particulate inorganic carbon content (PIC) of the calcareous nannoplankton (grey), excluding calcispheres (black) (see Methods). Cell size maxima at $300 \mathrm{kyr}$ and $4.25 \mathrm{Myr}$ after the $\mathrm{K} / \mathrm{Pg}$ given in grey italics. Key milestones/observations from herein and from published records are indicated (see Methods). *The level for the end acmes is taken as the top of the Praeprinsius acme. $\mathbf{f}$, Carbon isotope gradient $\left(\Delta \delta^{13} \mathrm{C}\right)$ between Walvis Ridge (WR, ODP Site 1262) planktonic and benthic foraminifera species (ref 9, using adjustment option 2), grouped according to ecology (blue - surface survivors, green - surface symbiotic, orange - thermocline, black - mixed layer, grey - transitional).

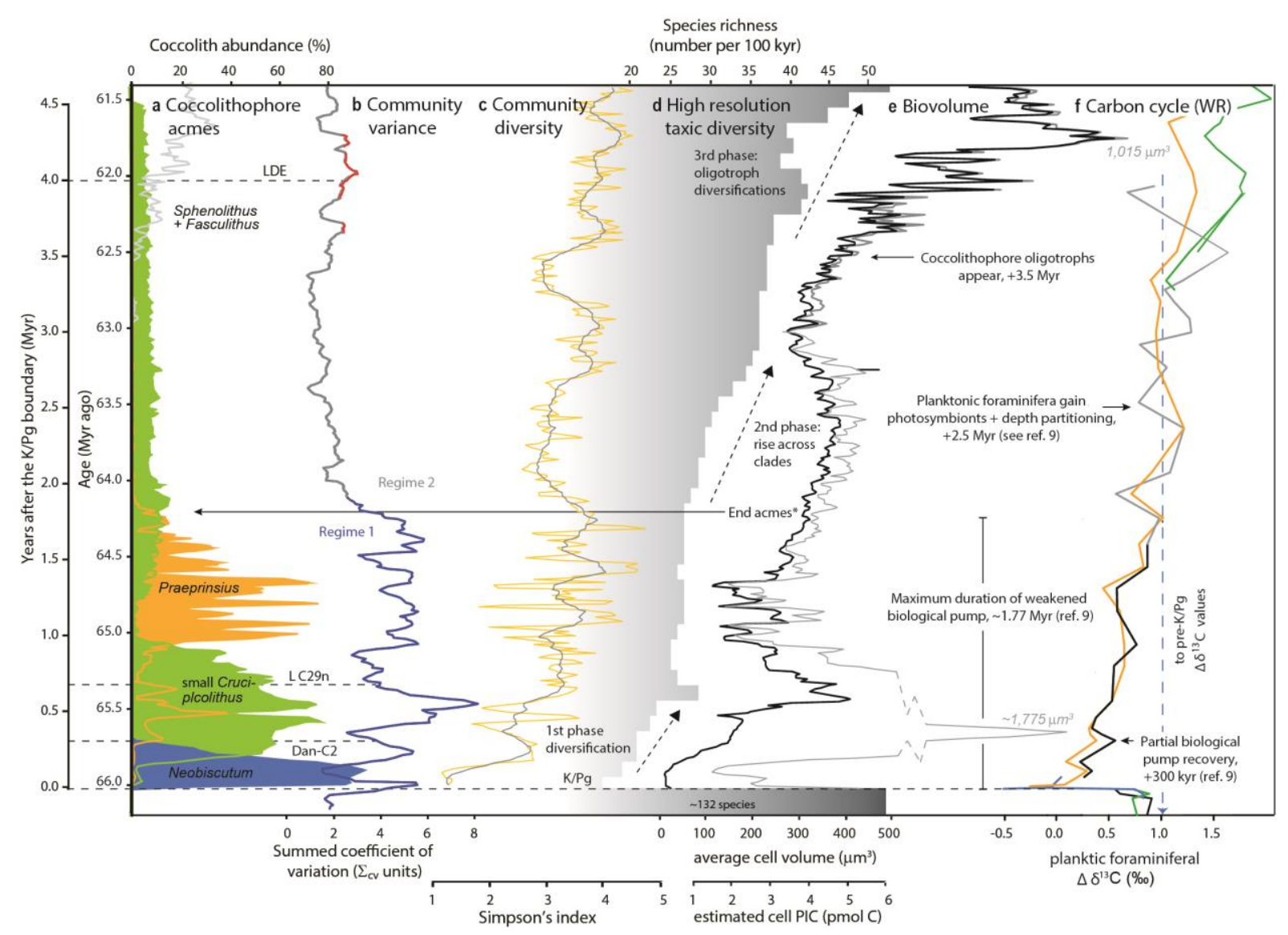


289 Experimental Design. Our objective was to characterize the emergence of resilience in plankton communities in the aftermath of the Cretaceous-Palaeogene $(\mathrm{K} / \mathrm{Pg})$ mass extinction and assess implications for higher trophic levels and biogeochemical cycling of the oceans. This work is the first palaeoecological study to present sustained very-high resolution sampling (13 kyr) over such a long duration (13 million years), maintaining sampling intensity across both event and background stratigraphic intervals. To achieve this, we required a continuous long time-series record from a single location that was representative of global patterns, all features satisfied by the open ocean, gyre location of Ocean Drilling Program (ODP) Site 1209. The palaeogeography and overall oceanic setting varied little at this site across the $13 \mathrm{Myr}$ record and calcareous nannoplankton provide the most consistent, high abundance fossil record of nannoplankton. This site has an orbitally-resolved age model, providing millennial sampling precision alongside high-resolution geochemical proxy records of palaeoenvironmental change ${ }^{31}$. Furthermore, the site is far from the Yucatan bolide impact and samples the dominant ocean basin of the early Cenozoic, providing the potential to track marine ecosystem recovery on a quasi-globally representative basis (see $c$ GENIE section below).

Sampling strategy. The nannoplankton assemblage data come from a $\sim 54$ metre section of the composite splice ${ }^{33}$ at ODP Site 1209 Shatsky Rise, in the palaeo-subequatorial Pacific Ocean (Extended Data Fig. 1). 981 samples were taken at $13 \mathrm{kyr}$ intervals, extending from the K/Pg boundary (66 Myr ago) through to the Palaeocene-Eocene Thermal Maximum (PETM: 56 Myr ago) and overlap the Eocene record of ref 21, giving a 13-Myr long record in total. Ages assigned to each sample use age models constructed for ODP Site 1209 by ref 34 and ref 35 (option 2), updated by ref 32 . The age model uses tie-points in the $\delta^{13} \mathrm{C}$ data correlated with the orbitally-tuned stratigraphy of ODP Site 1262, as summarized by ref 20 and ref 32 .

Assemblage data. Smear slides were prepared for nannofossil observation using standard techniques ${ }^{36}$. Assemblage data (Extended Data Fig. 3) are based on statistically significant counts of 500 to 1000 nannofossil liths per sample across a minimum of 10 fields of view, following identical count and taxonomic protocols of the Eocene record from ref 21 ( 218.5 to $208.0 \mathrm{rmcd}, \sim 56$ to $53 \mathrm{Ma}$ ). The assemblage data were counted to generic level, with some additional division into useful morphogroups (e.g., determined by genus and size, see below). Taxonomy generally follows refs 37-39. Visual assessment of preservation, as well as quantitative counts of lith fragmentation and presence of delicate lith structures, indicates that the nannofossils are generally well preserved but show some signs of etching and minor overgrowth, as is typical for carbonate-rich deep-sea sediments. Etching of delicate central area structures, particularly of Prinsiaceae specimens is common, but does not inhibit identification to genus level. While there is always some degree of variation in preservation quality through a long time-series such as this, our observations show that dissolution has not disproportionately distorted the assemblage character at any particular level or interval. This includes the hyperthermals where carbonate dissolution often increases (see ref 21) and, conversely, the immediate post-K/Pg interval where indicators suggest enhanced preservation $^{40}$. Of note, the later absence of the exclusively-small taxa, Neobiscutum, small Praeprinsius and Futyania, is an evolutionary signal confirmed in sections worldwide ${ }^{15}$, rather than a preservational artefact. There is evidence of reworking of Cretaceous taxa 
immediately above the K/Pg boundary at Site 1209 (Extended Data Fig. 3), but these specimens have not been included in the relative abundance calculations.

Summed coefficient of variation $\left(\Sigma_{\mathbf{C v}}\right)$. We have used a range of approaches (see below) to characterise community structure but focus on the $\Sigma_{\mathrm{CV}}$ time-series as it best encapsulates the key trends in community variance and relationships with environmental perturbation. The $\Sigma_{\mathrm{CV}}$ method is an analytical technique that is independent of taxic composition, and enables efficient collection and integration of large amounts of abundance data giving equal weighting to each of the taxa included ${ }^{21}$. When applied to microfossil data, it highlights the nuances of biotic response across a very broad spectrum of perturbations. We follow the same procedure as ref 21 but without using the SiZer smoothing step because we are not comparing datasets from different sources. First, the assemblage data, collected from samples taken every $\sim 5.5 \mathrm{~cm}$ (equivalent to every $13 \mathrm{kyr}$ ) were placed on the age scale and linearly resampled using AnalySeries version $2.0^{41}$ to provide consistent $13 \mathrm{kyr}$ spacing between datapoints. Second, we determined which taxa would be included for subsequent $\Sigma_{\mathrm{CV}}$ analysis. Because the $13 \mathrm{Myr}$ record includes significant evolution in community taxonmakeup, we divided the section into million-year bins and determined the most abundant and consistently present ( $>65 \%$ of samples) taxa in each. This resulted in the selection of 8 taxa across each bin - a relatively low number because of the low diversity in the early Danian but representing $>95 \%$ of the total population in each sample. We then followed the $\Sigma_{\mathrm{CV}}$ method of calculating coefficients of variation summed across these taxa using a moving window duration of $150 \mathrm{kyrs}$. As the $\Sigma_{\mathrm{CV}}$ metric quantifies the levels of variance across multiple taxa, our use of the term stability here refers to consistent and low levels of change in the abundance distribution across the main taxa. The term stability is used in ecology in a myriad of ways but in this case, we use a simple and intuitive definition of stability as meaning a system with low variability (i.e., little deviation from its average state; following ref 42) - a definition we think is most directly applicable to geological time-series data.

$\Sigma_{\mathrm{CV}}$ sensitivity tests. We have applied a range of sensitivity tests to the $\Sigma_{\mathrm{CV}}$ metric record, examining for the effects of sample window duration, taxon dominance, ancestry, fossil preservation, sedimentation rate and hiatuses (see also ref 21). Extended Data Figure 5 explores the impact of varying window duration and reveals how variance is packaged through time, as well as any differences resulting from analysing the data in time versus age domains. $\Sigma_{\mathrm{CV}}$ increases with increasing window-duration in the lower Danian, indicating that the window is capturing additional variance that is spread throughout the interval. By contrast, $\Sigma_{\mathrm{CV}}$ decreases with increasing window-duration across the PETM and ETM2, indicating focused variance, with little additional variance in the broader time window diluting the signal. We have explored the impact of shared ancestry because our analyses give equal weight to each taxonomic unit potentially introducing artificially high variance. We have tested for this by re-analysing the data using two additional models of shared ancestry developed from our genus-level stratophenetic tree (Extended Data Fig. 6). Sensitivity of the $\Sigma_{\mathrm{CV}}$ metric decreases as more genera are grouped, damping levels of variance (Extended Data Fig. 7), particularly when merging abundant genera from the same family (the highly conservative ancestry Option 1). However, the main patterns of variance still remain as robust features (as they do in the dissimilarity index described below), particularly when more branches of the tree are conserved (the moderately conservative ancestry Option 2). 
377 Dissimilarity and diversity metrics. We have calculated additional metrics of assemblage structure, namely Bray-Curtis Dissimilarity (BC; a metric that highlights structural differences in abundance and composition); the Simpson's index (SI; an evenness/dominance metric that incorporates abundance distribution and taxic richness), and the standard deviation (variance) of the SI (Extended Data Fig. 2). BC was performed on the maximum and minimum abundance values across the 11 samples within each moving $150 \mathrm{kyr}$ window, returning the maximum dissimilarity value. The values have been plotted for each moving $150 \mathrm{kyr}$ window through the time-series. BC is sensitive to taxonomic turnover (shown by increasing values with increasing window size, Extended Data Fig. 5b) but the impact is minimised using the $150 \mathrm{kyr}$ window, as species turnover is low. The standard deviation (variance) of SI was calculated from the 11 samples in each $150 \mathrm{kyr}$ moving window. The $\Sigma_{\mathrm{CV}}$ and BC time-series patterns are very similar $\left(\mathrm{R}^{2}\right.$ of $\left.63 \%\right)$ but the BC record differs in the amplitude of variation through background intervals because it is influenced, to varying degrees through the time-series, by rare taxa. SI is also highly sensitive to rarer taxon abundances and the rare, variable occurrences of taxa close to their appearance and/or disappearance.

Species richness estimates. The new species richness diversity data is an update of the global compilation of ref 3 . We have added new taxa described since 2004, increased the temporal resolution to $250 \mathrm{kyr}$ stratigraphic bins for the entire dataset (Fig. 1 and Extended Data Fig. 4) and 100-kyr bins for the Danian (Fig. 3), and present the data on the GTS2012 timescale $^{43}$. The species richness is the total number of taxa that occur for some part of, or throughout, each stratigraphic bin. Species richness estimates are dependent on the bin duration, hence the difference between the values in Figures $1 \mathrm{f}$ and $3 \mathrm{~d}$.

Cell size and volume. Estimates of average cell volume (Fig. 3 and Extended Data Fig. 4) are based on mean cell size per taxon weighted according to their abundance in the community at any given time.

Average cell volume $\left.=\left(\left(\left(\left(\% \mathrm{~T}_{\mathrm{ra}} \mathrm{x} \Theta \mathrm{T} 1_{\mathrm{av}}\right)+\left(\% \mathrm{~T} 2_{\mathrm{ra}} \times \Theta \mathrm{T} 2_{\mathrm{av}}\right)+\left(\% \mathrm{~T} 3_{\mathrm{ra}} \times \Theta \mathrm{T} 3_{\mathrm{av}}\right) \ldots . . \mathrm{Tn}\right] / 2\right)^{3}\right) / 3 \times 4 \pi\right) / \Sigma \% \mathrm{~T}_{\mathrm{ra}}$

404

405

406

407

408

409

410

411

412

413

414

415

416

417

418

419

420

421

Where $\% \mathrm{~T} 1_{\mathrm{ra}}$ is the $\%$ relative cellular abundance of the taxon in the total assemblage and $\Theta \mathrm{T} 1_{\mathrm{av}}$ is the average cell diameter of the taxon.

Cell diameter uses the internal diameter of coccospheres and cellular abundances were estimated by dividing the relative abundance of liths present by the average number of liths per cell. Coccosphere size and lith number for each taxon use (i) direct coccosphere measurements from coeval samples at ODP Site 1209 (Shatsky Rise), and also from Integrated Ocean Drilling Program (IODP) Sites 1403 and 1407 (North Atlantic), and from published scanning electron microscope (SEM) images of coccospheres ${ }^{44,45}$; (ii) coccolith measurements from these same samples converted to estimated cell size (and associated lith number) based on taxon-specific relationships between lith size, lith number and cell size determined from Palaeogene taxa within the same genus or family ${ }^{46}$; or (iii) estimates using modern analogues ${ }^{46}$ (details in Extended Data Table 1). For the calcareous dinocysts, we took a conservative estimate of cell diameter of 20 microns, based on light microscope and SEM images of complete dinocyst coverings from the lowermost Danian of ODP Site 1210 (Shatsky Rise) and divided raw calcareous dinocyst fragment counts by 12, as an estimate of how many fragments constitute a whole cell. Estimated particulate inorganic carbon per cell uses the least-squares linear regression between cell volume and cell PIC in Figure $4 \mathrm{c}$ of ref. 46. 

illustrate the palaeo-hydrographic location of Site 1209 using the ' $c$ GENIE' Earth system model. In this simulation, $c$ GENIE is configured with late Maastrictian boundary conditions of continental configuration, bathymetry, and wind stress as described in ref 47 . Additionally, the solar constant is reduced appropriate for $66 \mathrm{Myr}$ ago and atmospheric $\mathrm{CO}_{2}$ is set to 1112 ppm ( $\times 4$ pre-industrial). We take the $10 \mathrm{kyr}$ spin-up described in ref 47 and run this on for 10 more years, showing the results of the last year of the 10-year follow-on experiment in Extended Data Figure 1 as an annual average. ODP Site 1209 was slightly to the north (ca. ocean current field that is circumequatorial (Extended Data Fig. 1b) and links the major ocean basins. In the simulated late Maastrictian climate, temperatures do not fall more than about $6^{\circ} \mathrm{C}$ cooler than those at the location of Site $1209\left(35^{\circ} \mathrm{C}\right)$, nor exceed this, anywhere along the flow path by more than a few degrees $\mathrm{C}$. Further, from simple visual inspection of the $c$ GENIE simulations (Extended Data Fig. 1), the deflection of the circumequatorial current south of China and SE Asia to latitudes of ca. $10^{\circ} \mathrm{S}$ and interaction with the South Pacific subtropical gyre, suggest the potential for significant surface-water mixing to occur between the hemispheres. We conclude from this that Site 1209 is likely to be sampling the same tropical and partly sub-tropical plankton communities that occur in all major ocean basins and both hemispheres. The area of connected waters in the $28-38^{\circ} \mathrm{C}$ range is over $50 \%$ of the global ocean surface. The obvious exceptions to this global connectivity are the Arctic (being characterized by much cooler temperatures) and the South Atlantic (which exchanges with the Pacific primarily only to the South of Africa, with the cooler water regime in this ocean gateway representing a potential barrier to the mixing of tropical plankton communities globally).

Palaeogene climate events. A number of significant climate events occur through the 13 Myr study interval, including named transient events marked by isotopic excursions and identified on Figures 1 and 3, with further details provided in Extended Data Table 2. These are mainly global warming hyperthermal events identified by carbon and oxygen isotope excursions and associated deep-sea carbonate dissolution. Events I2, I1, H2, H1 and the PETM were recognised at ODP Site 1209 by examination of benthic and bulk carbon isotope values and magnetic susceptibility data, following refs 21 and 32. The PETM was also identified in benthic carbon isotope values and XRF Fe intensity data, following refs 35, 48. The Palaeocene Carbon Isotope Maximum (PCIM); Early Late Palaeocene Event (ELPE); Latest Danian Event (LDE) and the K/Pg boundary were identified in benthic carbon isotope values and XRF Fe intensity data ${ }^{48}$, and the positions of the PCIM and LDE were verified against records from ODP Site $1262^{49}$. The Lower C29n and Dan-C2 events are not clear in the benthic carbon isotope data at ODP Site $1209^{48}$, but were identified following ref 50, who suggest that the peaks in magnetic susceptibility ${ }^{51}$ and XRF Fe intensity ${ }^{35}$ identified as Pa2 and Pa1 by ref 35 correlate with the Lower C29n and Dan-C2 events, respectively. The position of the Dan-C2 is consistent with estimates for the timing of this event ${ }^{34,52}$.

Relationships between variance and carbon isotope excursion magnitude. For each climate event we use the carbon isotope excursion (CIE) magnitude as a proxy for the level of environmental perturbation, as illustrated by the scaling of temperature change with CIE size for several of the Eocene hyperthermals ${ }^{53}$. For the purposes of comparing environmental perturbation and $\Sigma_{\mathrm{CV}}$ (Fig. 2), we plot magnitude of CIE using a combination of size of excursion as recorded at ODP Site 1209 and the magnitude of excursion estimated from 
published bulk carbon isotope data at globally distributed sites (Extended Data Table 2). We used the maximum recorded excursion, except where this was inconsistent with other available data. As well as values from bulk carbon isotope data (consistent with ref 21), we took into account available benthic CIE values, which are arguably preferable for resolving global signals ${ }^{54}$. The value of carbon isotopes used for plotting non-event $\Sigma_{\mathrm{CV}}$ data points in Figure 2 uses the deviation of the carbon isotope value from the detrended running average (using an 11-point running average through non-event-only values), for a data-point every $\sim 150 \mathrm{kyr}$ between climatic events. We regressed first differences in $\Sigma_{\mathrm{CV}}$ and first differences in CIE magnitude (Fig. 2b) to statistically explore the relationship between community stability and climate change across this 13-million-year interval, using a generalised least squares framework (gls function in the nlme library in R) that applies best-fit models that incorporate heteroscedastic (non-constant variance with the mean) and temporally autocorrelated (time-series) errors.

Milestones (Figure 3). Biological pump reboot (0.30 Myr) and recovery (1.77 Myr): Carbon isotope records of benthic and planktonic foraminifera from Walvis Ridge (southern Atlantic), adjusted to account for vital effects and ecology, show a crash in surface- to deepwater carbon-isotope gradients at the mass extinction level and indicate that transfer of organic matter to the deep-sea via the biological pump was severely perturbed ${ }^{9}$. These records show that vertical gradients were close to zero for the initial $0.3 \mathrm{Myr}$ after the extinction, then slowly increased to attain pre-extinction levels at around $1.77 \mathrm{Myr}$. This is interpreted as evidence that the duration of weakened biological pumping was no longer than 1.77 Myrs $^{9}$, providing an estimate for full biological pump recovery. Photosymbiosis and depth partitioning in planktonic foraminifera (2.5 Myr): Based on reconstructions of the palaeoecology of planktonic foraminifera using the oxygen and carbon stable isotopes of their shells, the appearance of photosymbiosis and expansion of depth partitioning both occur around 2.5 Myr after the mass extinction ${ }^{9,55}$. Appearance of oligotrophic coccolithophores (3.5 Myr): The first appearance of early fasciculiths and sphenoliths represent the earliest representatives of the Discoasterales group, which is largely characterized by oligotrophic taxa (e.g., ref 28). The earliest representatives, Fasciculithus magnus and F. magnicordis, appear at $\sim 63 \mathrm{Myr}$ ago (herein; ref 56) with other fasciculiths and sphenoliths following soon after (62.13 and 61.98 Myr ago, according to ref 43).

Selected taxonomic notes. Praeprinsius: used here to include very small $(<3 \mu \mathrm{m})$ circular to subcircular specimens of Praeprinsius tenuiculum. Praeprinsius is considered a synonym of Prinsius by some, but we consider these groups to be morphologically distinct. Fasciculithus: We use 'early fasciculiths' to include specimens that some may now identify as Gomphiolithus, Diantholitha, and Lithoptychius (e.g., refs 56,58,59), while our main 'Fasciculithus' group includes taxa that have been consistently classified within this genus, e.g., F. involutus and F. tympaniformis. Sphenoliths: The earliest specimens of the genus Sphenolithus (e.g., refs 56,60) are highly variable and we distinguish between the earliest incoming specimens (termed 'early sphenoliths') and the main generic group 'Sphenolithus', 


\section{References for Methods and Extended Data}

33. Westerhold, T. \& Röhl, U. Data report: Revised composite depth records for Shatsky Rise Sites 1209, 1210, and 1211. in Proceedings of the Ocean Drilling Program, Scientific Results 198 (eds. Bralower, T. J., Premoli-Silva, I. \& Malone, M. J.) 1-26 (2006).

34. Dinarès-Turell, J., Westerhold, T., Pujalte, V., Röhl, U. \& Kroon, D. Astronomical calibration of the Danian stage (Early Paleocene) revisited: Settling chronologies of sedimentary records across the Atlantic and Pacific Oceans. Earth Planet. Sci. Lett. 405, 119-131 (2014).

35. Westerhold, T. et al. Astronomical calibration of the Paleocene time. Palaeogeogr. Palaeoclimatol. Palaeoecol. 257, 377-403 (2008).

36. Bown, P. R. \& Young, J. R. Techniques. in Calcareous Nannofossil Biostratigraphy (ed. Bown, P. R.) 16-28 (Chapman \& Hall, 1998).

37. Perch-Nielsen, K. Cenozoic calcareous nannofossils. in Plankton Stratigraphy (eds. Bolli, H. M., Saunders, J. B. \& Perch-Nielsen, K.) 427-555 (Cambridge University Press, 1985).

38. Bown, P. R. Paleocene calcareous nannofossils from Tanzania (TDP sites 19, 27 and 38). J. Nannoplankt. Res. 36, 1-32 (2016).

39. Young, J. R., Bown, P. R. \& Lees, J. A. Nannotax3 website. (2019). Available at: http://www.mikrotax.org/Nannotax3/.

40. Bown, P.R., et al., A Paleogene calcareous microfossil Konservat-Lagerstätte from the Kilwa Group of coastal Tanzania. Geol. Soc. Am. Bull. 120, 3-12 (2008)

41. Paillard, D., Labeyrie, L. \& Yiou, P. Macintosh Program performs time-series analysis. Eos, Trans. Am. Geophys. Union 77, 379-379 (1996).

42. Cleland, E. E. Biodiversity and Ecosystem Stability. Nature Education Knowledge 3(10), 14 (2011).

43. The Geologic Time Scale 2012. (Elsevier, 2012).

44. Mai, H., Perch-Nielsen, K., Willems, H. \& Romein, A. J. T. Fossil Coccospheres from the K/T Boundary Section from Geulhemmerberg, the Netherlands. Micropaleontology 43, 281-302 (1997).

45. Mai, H., Hildebrand-Habel, T., Perch-Nielsen, K. V. S. \& Willems, H. Paleocene coccospheres from DSDP Leg 39, Site 356, Sao Paulo Plateau, S Atlantic Ocean. J. Nannoplankt. Res. 20, 21-29 (1998).

46. Gibbs, S. J., Sheward, R. M., Bown, P. R., Poulton, A. J. \& Alvarez, S. Warm plankton soup and red herrings: calcareous nannoplankton cellular communities and the Palaeocene-Eocene Thermal Maximum. Philos. Trans. R. Soc. A 20170075 (2018). doi:10.1098/rsta.2017.0075

47. Schmidt, A. et al. Selective environmental stress from sulphur emitted by continental flood basalt eruptions. Nat. Geosci. 9, 77-82 (2016).

48. Westerhold, T., Röhl, U., Donner, B., McCarren, H. K. \& Zachos, J. C. A complete high-resolution Paleocene benthic stable isotope record for the central Pacific (ODP 
49. Littler, K., Röhl, U., Westerhold, T. \& Zachos, J. C. A high-resolution benthic stableisotope record for the South Atlantic: Implications for orbital-scale changes in Late Paleocene-Early Eocene climate and carbon cycling. Earth Planet. Sci. Lett. 401, 1830 (2014).

50. Coccioni, R. et al. The Dan-C2 hyperthermal event at Gubbio (Italy): Global implications, environmental effects, and cause(s). Earth Planet. Sci. Lett. 297, 298305 (2010).

51. Shipboard Scientific Party. Chapter 5: Site 1209. in Proceedings of the Ocean Drilling Program, Initial Reports 198 (eds. Bralower, T. J., Premoli-Silva, I. \& Malone, M. J.) 1-102 (2002). doi:10.2973/odp.proc.ir.198.105.2002

52. Westerhold, T., Röhl, U., Frederichs, T., Bohaty, S. M. \& Zachos, J. C. Astronomical calibration of the geological timescale: Closing the middle Eocene gap. Clim. Past 11, 1181-1195 (2015).

53. Stap, L. et al. High-resolution deep-sea carbon and oxygen isotope records of Eocene Thermal Maximum 2 and H2. Geology 38, 607-610 (2010).

54. Zeebe, R. E., Westerhold, T., Littler, K. \& Zachos, J. C. Orbital forcing of the Paleocene and Eocene carbon cycle. Paleoceanography 32, 440-465 (2017).

55. Birch, H., Coxall, H. K. \& Pearson, P. N. Evolutionary ecology of Early Paleocene planktonic foraminifera: size, depth habitat and symbiosis. Paleobiology 38, 374-390 (2012).

56. Monechi, S., Reale, V., Bernaola, G. \& Balestra, B. The Danian/Selandian boundary at Site 1262 (South Atlantic) and in the Tethyan region: Biomagnetostratigraphy, evolutionary trends in fasciculiths and environmental effects of the Latest Danian Event. Mar. Micropaleontol. 98, 28-40 (2013).

57. Bralower, T. J. Paleocene-Early Oligocene calcareous nannofossil biostratigraphy, ODP Leg 198 Sites 1209, 1210, and 1211 (Shatsky Rise, Pacific Ocean). in Proceedings of the Ocean Drilling Program, Scientific Results 198 (eds. Bralower, T. J., Premoli Silva, I. \& Malone, M. J.) 1-15 (2005).

58. Aubry, M.-P., Bord, D. \& Rodriguez, O. New taxa of the Order Discoasterales Hay 1977. Micropaleontology 57, 269-288 (2011).

59. Monechi, S., Reale, V., Bernaola, G. \& Balestra, B. Taxonomic review of early Paleocene fasciculiths. 58, Micropaleontology 351-365 (2012).

60. Agnini, C. et al. High-resolution nannofossil biochronology of middle Paleocene to early Eocene at ODP Site 1262: Implications for calcareous nannoplankton evolution. Mar. Micropaleontol. 64, 215-248 (2007).

61. van Heck, S. E. \& Prins, B. A refined nannoplankton zonation for the Danian of the Central North Sea. Abhandlungen der Geol. Bundesanstalt 39, 285-303 (1987).

62. Sáez, A.G., Probert, I., Young, J.R., Edvardsen, B., Wenche, E. \& Medlin, L.K. A review of the phylogeny of the Haptophyta. in Coccolithophores - from molecular processes to global impact (eds Thierstein, H.R. \& Young, J.R.) 251-270 (Springer 2004). 
63. Young, J.R., Geisen, M. \& Probert, I. A review of selected aspects of coccolithophore biology with implications for palaeobiodiversity estimation. Micropaleontology, 51, 267-288 (2005).

64. Young, J.R., Liu, H., Probert, I., Aris-Brosou, H. \& de Vargas, C. Morphospecies versus phylospecies concepts for evaluating phytoplankton diversity: the case of the Coccolithophores. Cryptogamie, Algologie 35, 353-377 (2014).

65. Cramer, B. S., Wright, J. D., Kent, D. V. \& Aubry, M. P. Orbital climate forcing of $\delta 13 \mathrm{C}$ excursions in the late Paleocene-early Eocene (chrons C24n-C25n). Paleoceanography 18, 1-25 (2003).

66. Nicolo, M. J., Dickens, G. R., Hollis, C. J. \& Zachos, J. C. Multiple early Eocene hyperthermals: Their sedimentary expression on the New Zealand continental margin and in the deep sea. Geology 35, 699-702 (2007).

67. Lourens, L. J. et al. Astronomical pacing of late Palaeocene to early Eocene global warming events. Nature 435, 1083-1087 (2005).

68. Zachos, J. C. et al. A transient rise in tropical sea surface temperature during the Paleocene-Eocene thermal maximum. Science 302, 1551-4 (2003).

69. Zachos, J. C. et al. Rapid acidification of the ocean during the Paleocene-Eocene Thermal Maximum. Science 308, 1611-1615 (2005).

70. Bernaola, G. et al. Evidence of an abrupt environmental disruption during the midPaleocene biotic event (Zumaia section, western Pyrenees). Bull. Geol. Soc. Am. 119, 785-795 (2007).

71. Quillévéré, F., Aubry, M.-P., Norris, R. D. \& Berggren, W. A. Paleocene oceanography of the eastern subtropical Indian Ocean: An integrated magnetobiostratigraphic and stable isotope study of ODP Hole 761B (Wombat Plateau). Palaeogeogr. Palaeoclimatol. Palaeoecol. 184, 371-405 (2002).

72. Arenillas, I., Molina, E., Ortiz, S. \& Schmitz, B. Foraminiferal and $\delta 13 \mathrm{C}$ isotopic event-stratigraphy across the Danian-Selandian transition at Zumaya (northern Spain): Chronostratigraphic implications. Terra Nov. 20, 38-44 (2008).

73. Bornemann, A. et al. Latest Danian carbon isotope anomaly and associated environmental change in the southern Tethys (Nile Basin, Egypt). J. Geol. Soc. London. 166, 1135-1142 (2009).

74. Jehle, S., Bornemann, A., Deprez, A. \& Speijer, R. Planktic foraminiferal response to the Latest Danian Event in the Pacific Ocean ( ODP Site 1210 ). 17, 9115 (2015).

75. Schmitz, B. et al. High-resolution iridium, $\delta 13 \mathrm{C}, \delta 18 \mathrm{O}$, foraminifera and nannofossil profiles across the latest Paleocene benthic extinction event at Zumaya, Spain. Palaeogeogr. Palaeoclimatol. Palaeoecol. 133, 49-68 (1997).

76. Schmitz, B., Molina, E. \& von Salis, K. The Zumaya section in Spain: A possible global stratotype section for the Selandian and Thanetian stages. Newsletters Stratigr. 36, 35-42 (1998).

77. Kroon, D., Zachos, J. C. \& Leg 208 Scientific Party. Cenozoic climate cycles and excursions. in Proceedings of the Ocean Drilling Program, Scientific Results 208 (eds. Kroon, D., Zachos, J. C. \& Richter, C.) 1-55 (2007). 
78. Quillévéré, F., Norris, R. D., Kroon, D. \& Wilson, P. A. Transient ocean warming and shifts in carbon reservoirs during the early Danian. Earth Planet. Sci. Lett. 265, 600615 (2008).

Acknowledgments This research used samples provided by the International Ocean

640 Discovery Program. We would like to thank the Royal Society for funding S.J.G. through a

641 URF. R.M.S. was funded jointly through a Vice Chancellor's studentship from the University

642 of Southampton and a Natural Environment Research Council (NERC) studentship (award

643 reference 1272561), and H.K. was part supported by a UCL Dean's prize. We would also like

644 to thank the European Union for post-doctoral research funding for S.A.A. (grant ERC-2013-

645 CoG-617303). A.R. was partly supported by an award from the Heising-Simons Foundation

646 as well as via grant ERC-2013-CoG-617303. We would like to thank Tom Ezard for

647 contributions to the interpretation of the datasets and Paul Wilson for his independent editing

648 of the manuscript.

649 Author contributions S.J.G., P.R.B. and A.R. conceived and designed the study. S.A.A.

650 developed the methodology and performed the majority of data collection. S.A.A. and S.J.G.

651 performed the data analyses. P.R.B., R.M.S., H.K. and A.R. contributed to data collection,

652 analysis and interpretation. S.J.G. and P.R.B. wrote the manuscript and A.R., S.A.A. and

653 R.M.S. participated in manuscript writing and editing.

654 Author Information Reprints and permissions information is available at

655 www.nature.com/reprints. The authors declare no competing interests. Correspondence and

656 requests for materials should be addressed to S.A.A. (sarah.alvarez@unigib.edu.gi) or S.J.G.

657 (sxg@noc.soton.ac.uk).

658 Data availability The datasets generated or analysed during this study are included in the

659 published article, linked directly to figures 1, 2 and 3 . 
Extended data figures:

Extended Data Figure 1. Location of ODP Site 1209 (black star) with respect to model simulated late Cretaceous major ocean current and circulation patterns. a, Barotropic streamfunction simulated in a late Cretaceous configuration of the $c$ GENIE Earth system model $^{47}$. b, Surface ocean current field (black arrows) for the same circulation state as (a) overlain on annual average ocean surface temperature (colours). Scale for current vectors on the right, along with a truncated temperature scale to highlight distribution of comparable
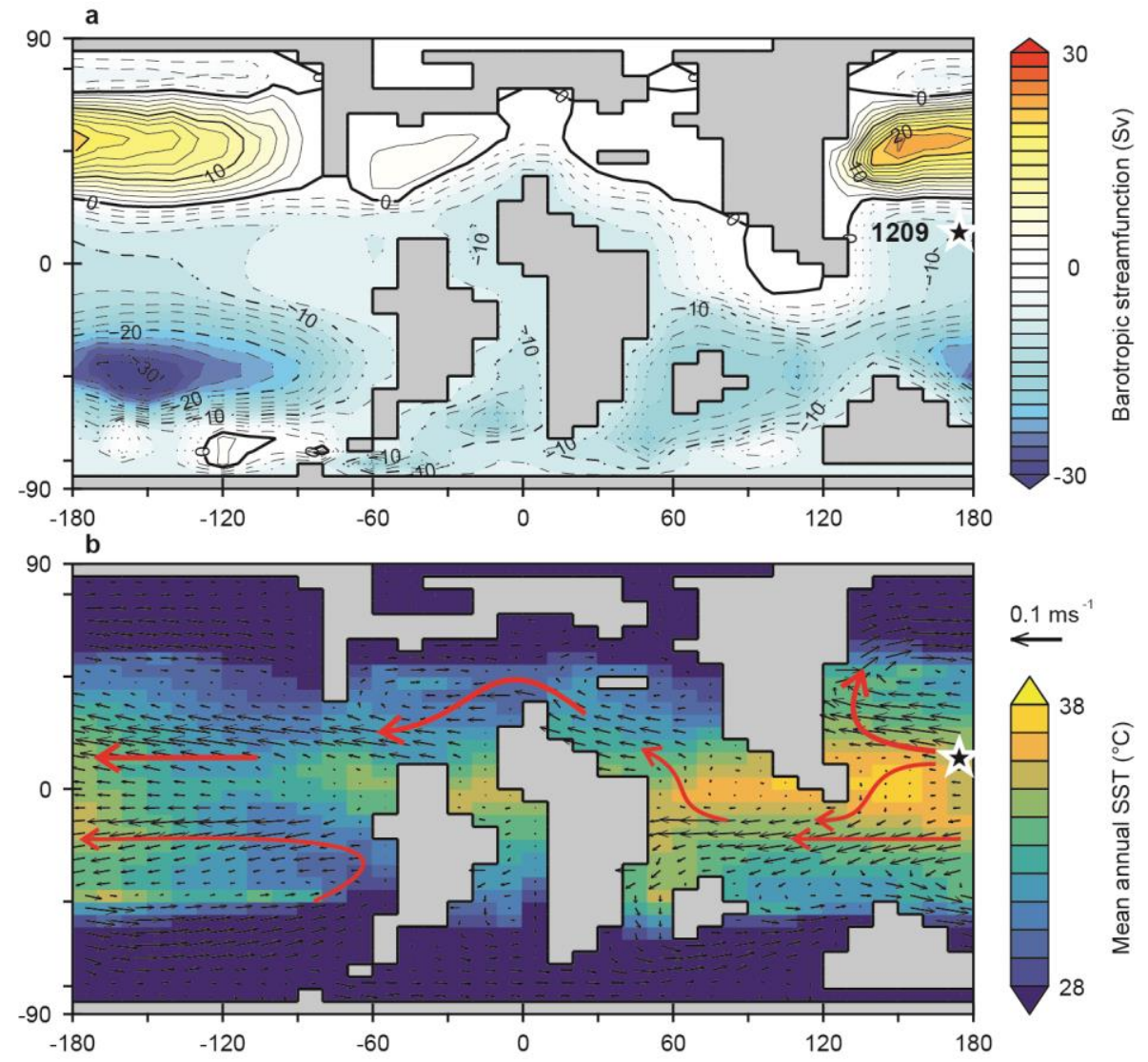
Extended Data Figure 2. Comparison of community structure metrics. Downcore plots of (a) $\Sigma_{\mathrm{CV}}$, (b) Bray-Curtis dissimilarity (BC), (d) Simpson's index (SI, grey dashed lines, $676150 \mathrm{kyr}$ moving average - black line) and the variance (150 kyr window) in the SI (c).

677 Vertical grey lines on $\mathbf{a}$ and $\mathbf{b}$ show the level of background inferred from rank order plots of these data. All four metrics ( $\Sigma_{\mathrm{CV}}, \mathrm{BC}, \mathrm{SI}$ and SI-variance) show volatility distinction between early Danian Regime 1 ( $\mathrm{n}=137$ data points) and Regime 2 (the rest of the record, $\mathrm{n}=861$ data points), e.g., the Wilcoxon Rank Sum value for the Simpson's record $=46646, p<0.001$ on first differences, with $95 \%$ confidence limits of $-0.013,-0.006$. A W value of zero would support a null hypothesis. The test was two-sided. SI shows a diversity minimum in the earliest Danian and then a rapid increase and steady long-term trend towards more diverse, more even communities, but with high variability in the early Danian. This SI fluctuation, as recorded by the record's variance (c) shows similar patterns to BC and $\Sigma_{\mathrm{CV}}$ with high variance in the early Danian before dropping down. SI variance also shows high background fluctuations and a sustained rise in amplitude of fluctuations around the PCIM isotope shift, reflecting oligotroph diversification, which the SI shows strongly due to its higher sensitivity to rare taxa. In effect, metric sensitivity to taxic richness and rare taxa increases from panel a to $\mathbf{c}$ (from abundance variance to diversity variance). Note - SI can only be performed on full assemblage data and therefore the record only extends up to $55.5 \mathrm{Myr}$ ago.

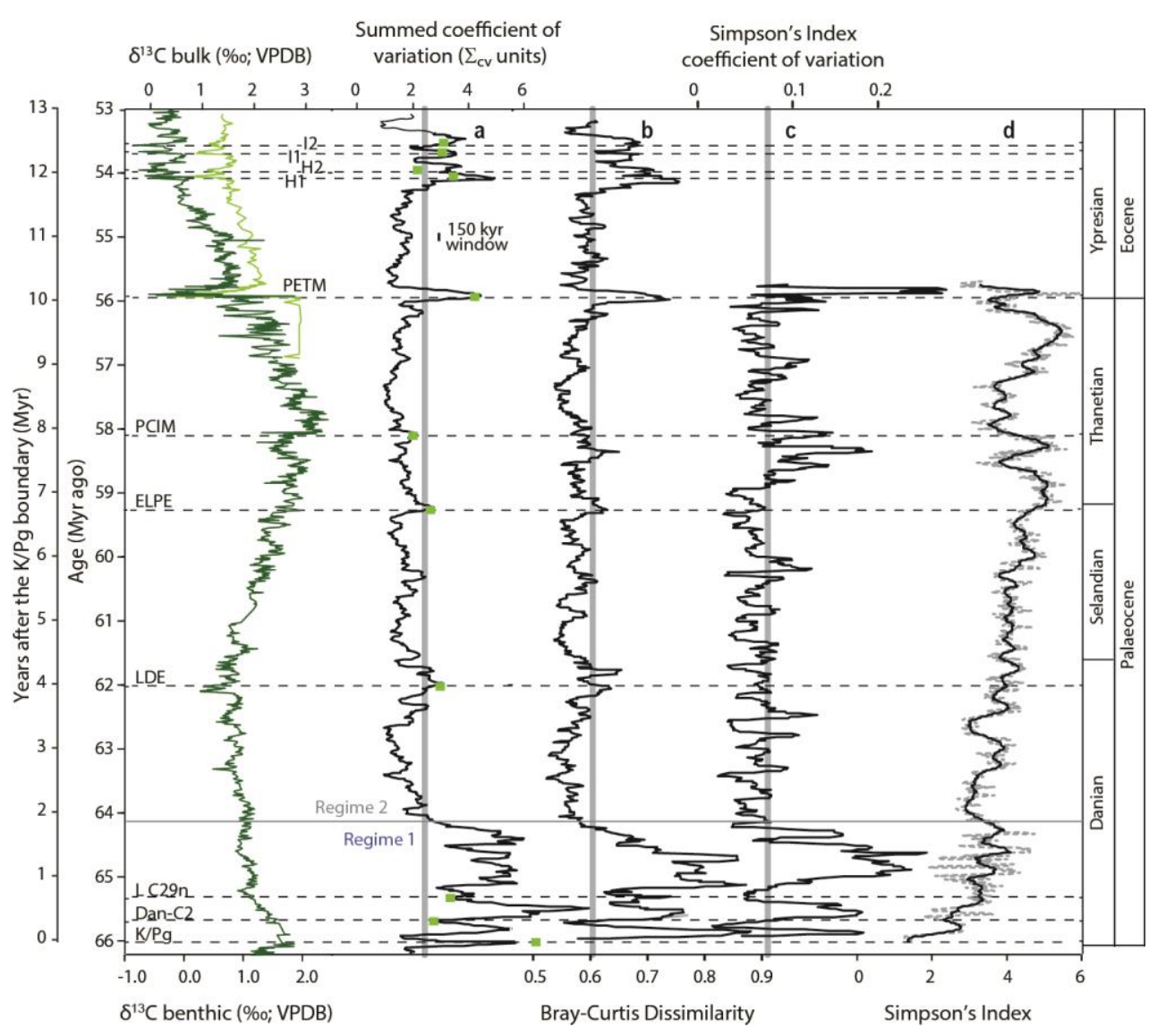



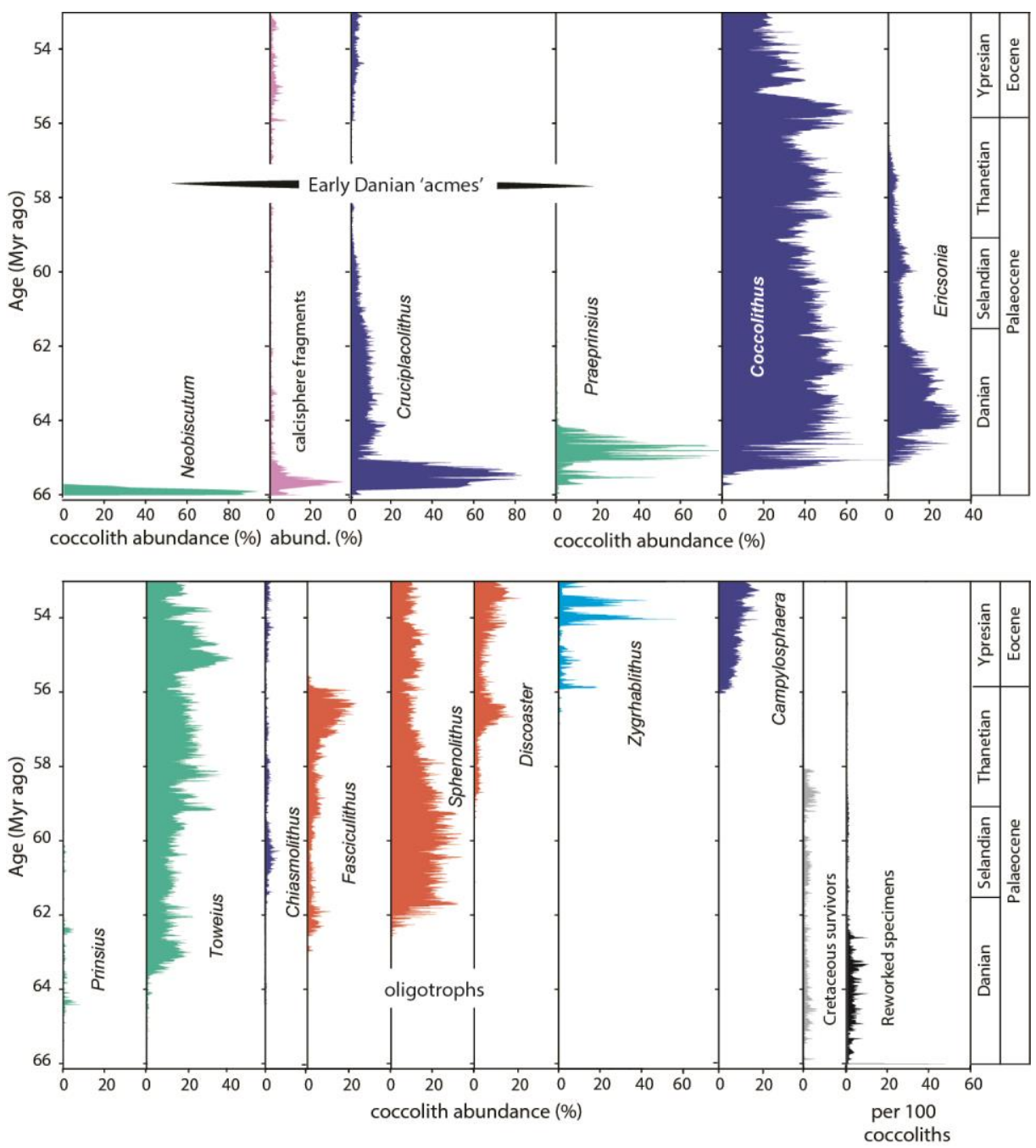
from all groups included in the $\Sigma_{\mathrm{CV}}$ metric are shown, coloured according to clade (as per Fig. 1b) and ordered by stratigraphic appearance. Cretaceous survivor taxa were counted as individual species but have been grouped together here, comprising mostly Zeugrhabdotus with lower abundances of Cyclagelosphaera, Markalius and Neocrepidolithus. abundance of reworked specimens per 100 nannofossils. Relative abundance of coccoliths 
Extended Data Figure 4. Calcareous nannoplankton across the K/Pg boundary.

Stratigraphic distribution of significant species grouped as incoming (brown), survivor (green) or disappearing taxa (blue). A subset of Cretaceous taxa are shown, with latest Maastrichtian diversity for families shown alongside number of survivors. Gradualistic evolutionary transitions indicated by close spacing and arrows indicate genus-level transitions. The nannoplankton data are primarily from our work but are largely consistent with published sources (e.g., refs 10,15,16,37,61). Diversity and cell-volume records from Figure 3. $C p .=$ Cruciplacolithus, Dan-C2, L C29n = hyperthermals, LDE = late Danian event, Neobisc. $=$ Neobiscutum, $\mathrm{NP}=$ nannofossil biozone, Prae.$=$ Praeprinsius .

713

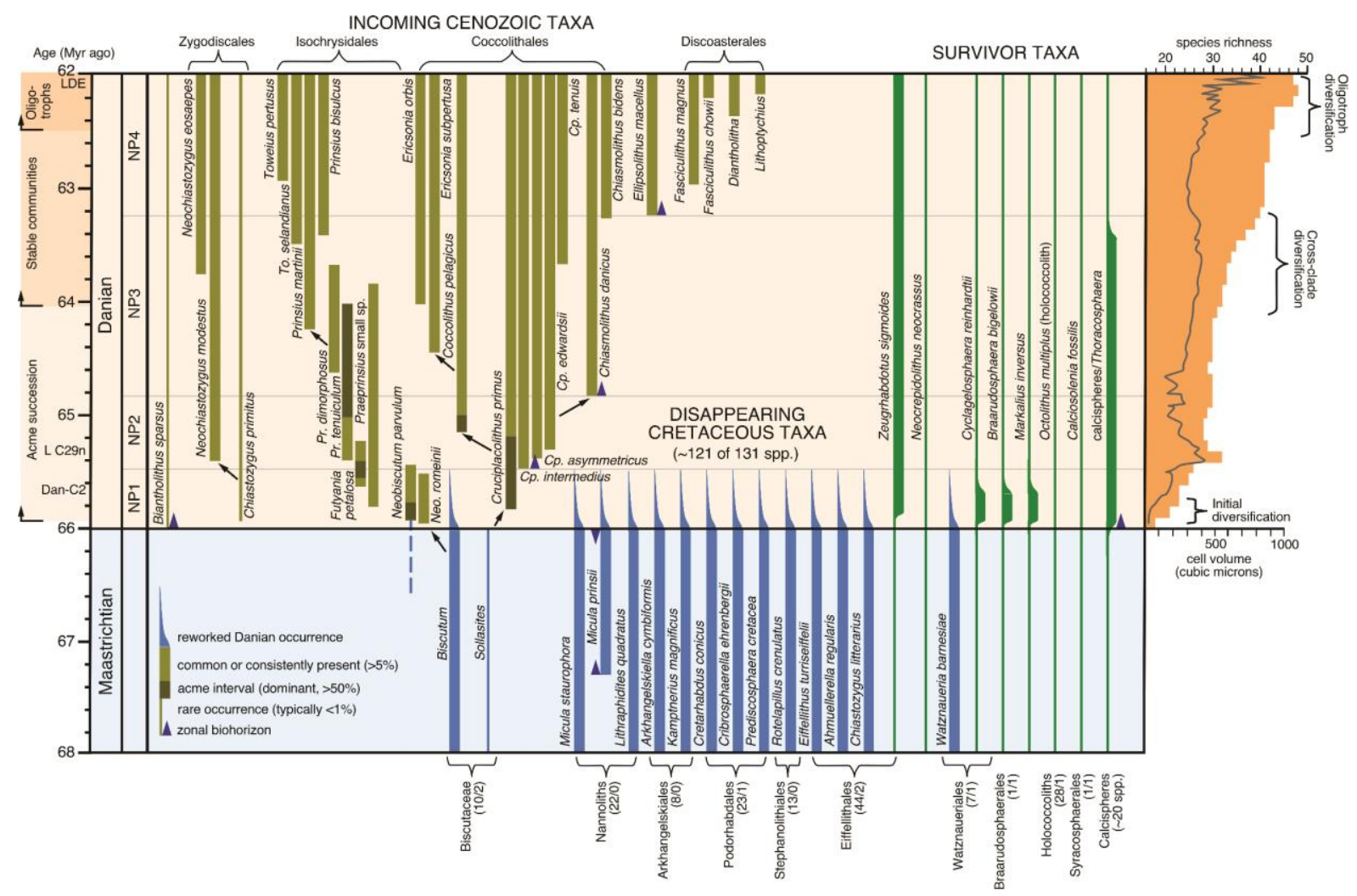



depth or age domain on the summed coefficient of variability $\left(\Sigma_{\mathrm{CV}}\right)$, and impact of window duration on Bray-Curtis dissimilarity (BC) (b). a, b, $\Sigma_{\mathrm{CV}}$ and $\mathrm{BC}$ calculated using different window durations (75-1000 kyr). c, side-by-side results of $\Sigma_{\mathrm{CV}}$ calculated using evenly spaced samples in either the depth domain or the age domain using a depth window duration of $60 \mathrm{~cm}$, which is broadly equivalent to the $150 \mathrm{kyr}$ time window. When $\Sigma_{\mathrm{CV}}$ is plotted in the depth domain the main patterns are retained, indicating that no significant artefacts arise from the applied age model. The boundaries between the million-year sections, where the taxa included in the $\Sigma_{\mathrm{CV}}$ change (black dots) are also marked on panel a and again there are no obvious artefacts across the million year windows with changes in the most abundant taxa.

727

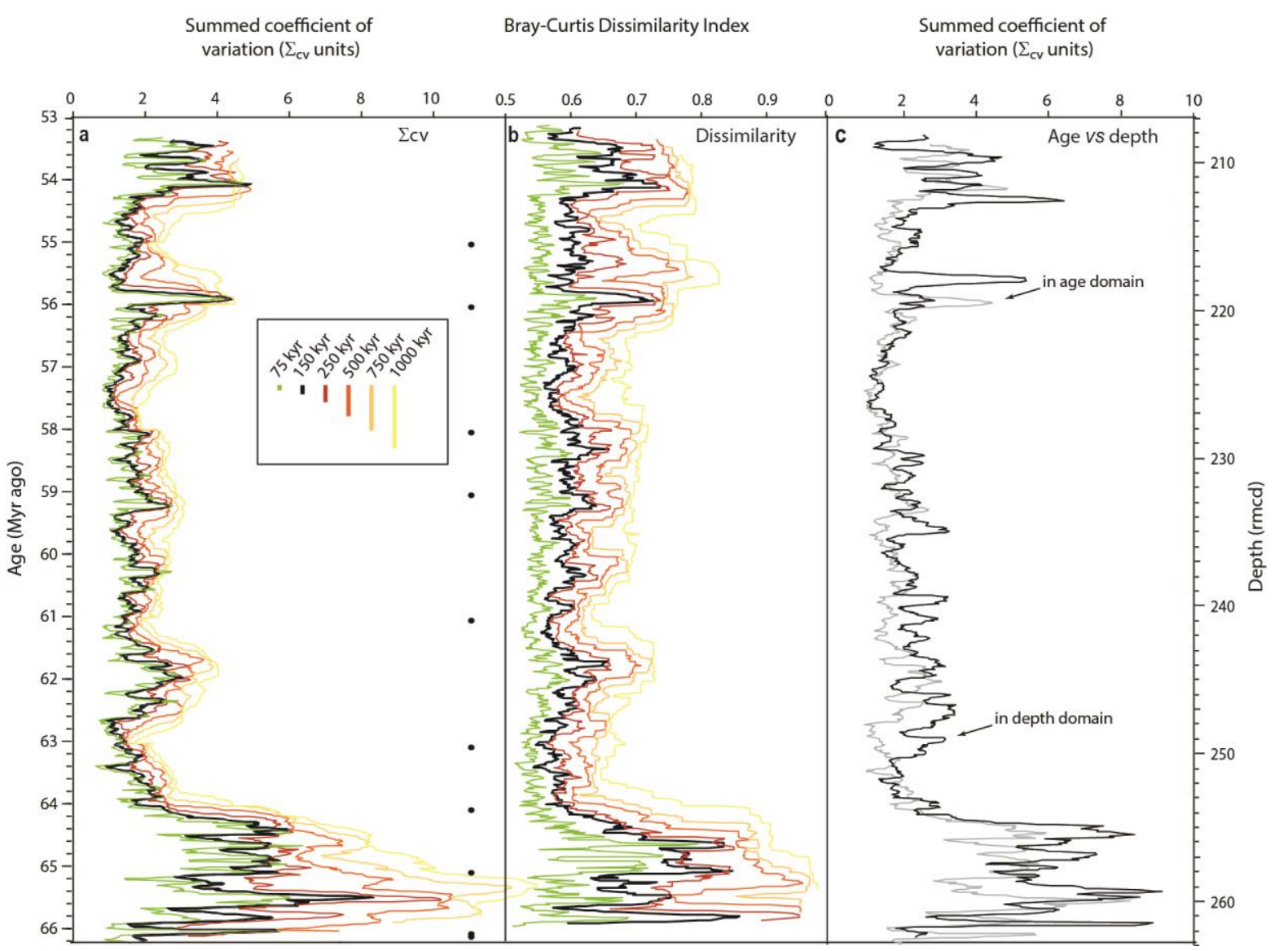


nannoplankton. Models range from a standard genus-level stratophenetic tree (a) through two successively conservative scenarios $(\mathbf{b}, \mathbf{c})$ grouping closely-related taxa, i.e., recently diverged taxa based on morphological and stratigraphic range data. Nannoplankton taxonomy is primarily based on the morphology and crystallographic ultrastructure of exoskeletal coccoliths but the addition of genetic data for modern taxa has confirmed that this approach is robust $^{62,63,64}$. Evolutionary models are stratophenetic because we have high-quality stratigraphic information but lack the range of meaningful homologous morphological characters to allow a cladistic analysis. a, genus-level phylogeny based on an extensive species-level stratophenetic tree. $\mathbf{b}$ and $\mathbf{c}$ are different ancestry options used to test for artefacts and sensitivity in variance/dissimilarity that may result from equal weighting of closely-related versus more distantly-related taxa. b, ancestry model option 1 is highly conservative and merges major sub-family groups (shown by shaded boxes) about five nodes shown by black circles. c, ancestry model option 2 merges the most closely-related genera (shaded boxes) about eight nodes.
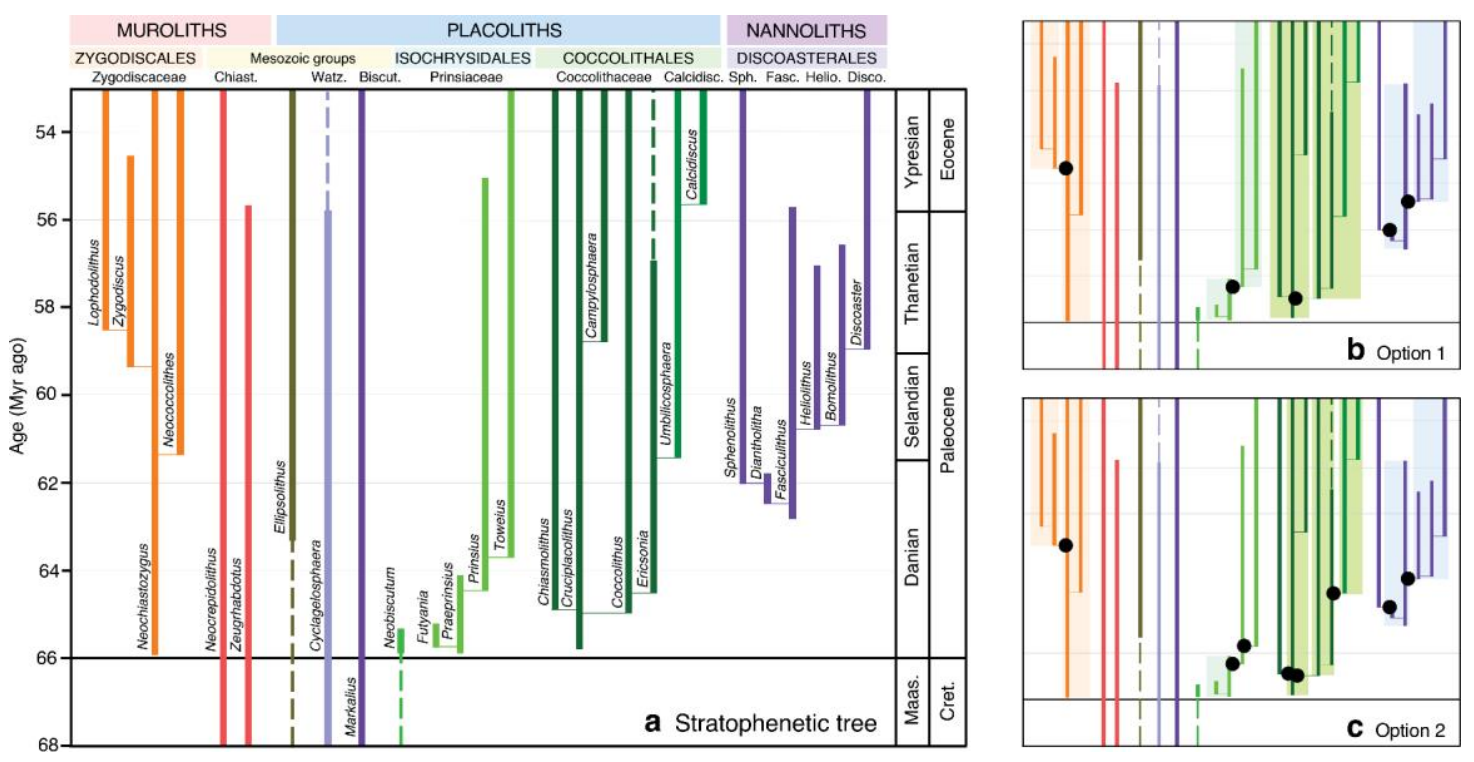

additional models of shared ancestry using the reconstructed genus-level stratophenetic tree in Extended Data Figure 6a. In red, the original analysis giving each genus equal. In grey, analysis of the conservative ancestry model that merges genera into major sub-family groups (ancestry model option 1, Extended Data Fig. 6b). In black, analysis of the moderately conservative ancestry model option 2 (Extended Data Fig. 6c) which merges the most closely-related genera. BC displays very little sensitivity to varying the taxonomic hierarchies. $\Sigma_{\mathrm{CV}}$ displays some sensitivity, particularly at the Late Danian Event (around 62 Myrs ago) but the main patterns are retained between the original and option 2. Some variance is lost in the less realistic option 1 analysis, where grouping of key genera that lie in the same families dampens the variance, in particular, in the early Danian. However, the early Danian variance values still remain anomalously high compared to the rest of the record.

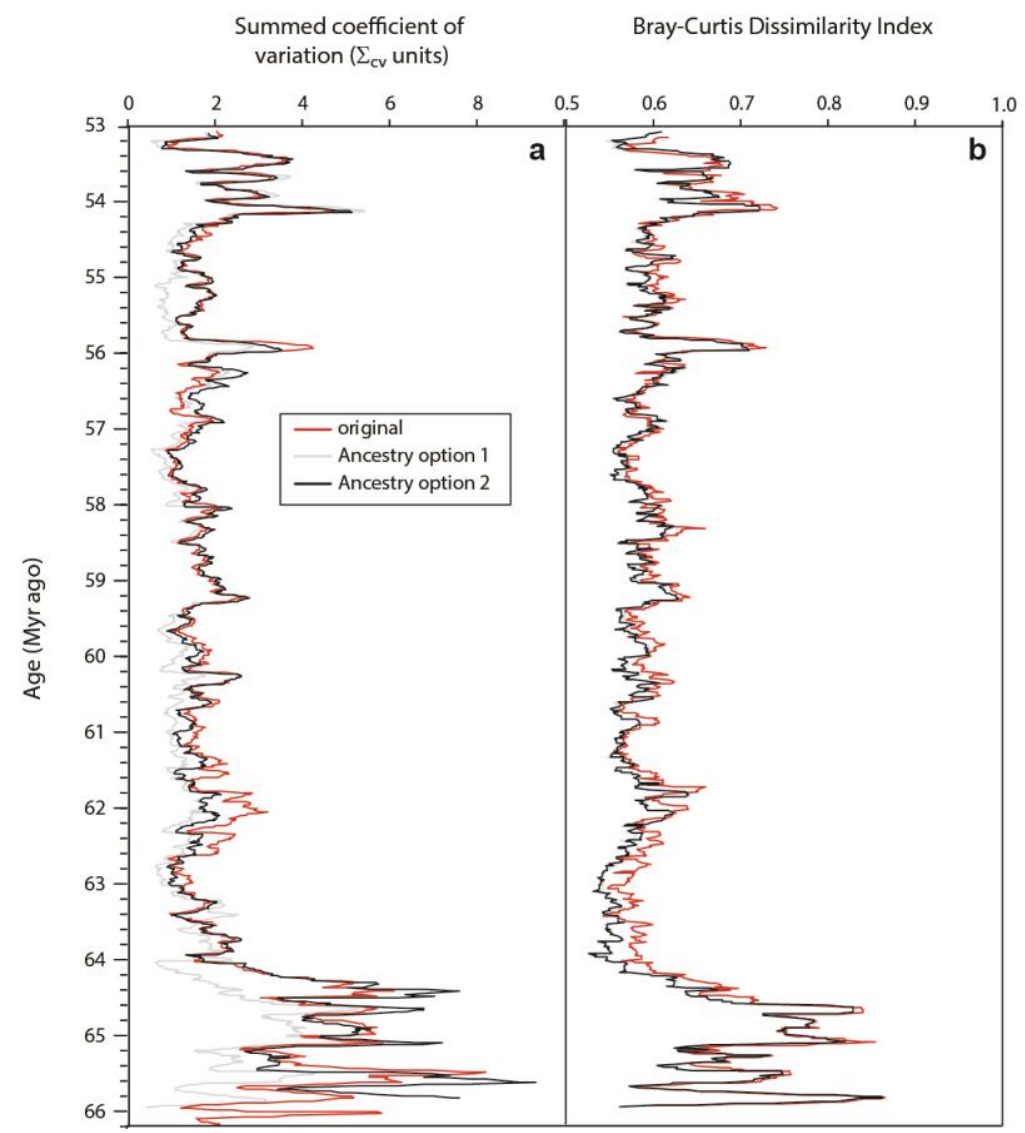



length. Sites referred to include ODP Site 1209 and IODP Sites 1403 and 1407. 'Pg coccospheres' refers to new coccosphere measurements for the Palaeogene. SEM images of published coccospheres are all from refs 44,45 .

\begin{tabular}{|c|c|c|c|c|c|}
\hline Clade & Taxon & $\begin{array}{l}\text { Lith } \\
\text { number } \\
\left(C_{N}\right)\end{array}$ & $\begin{array}{l}\text { Cell size }(\Theta, \\
\mu \mathrm{m})\end{array}$ & $\begin{array}{l}\text { Cell volume } \\
\qquad\left(\mu \mathrm{m}^{3}\right)\end{array}$ & Source \\
\hline \multirow[t]{4}{*}{ Cretaceous survivors } & Neocrepidolithus & 32.5 & 16.5 & 2352 & Ref. 46 \\
\hline & Zeugrhabdotus & 32.5 & 16.5 & 2352 & Ref. 46 \\
\hline & Markalius & 12 & 8.3 & 297 & Pg coccospheres \\
\hline & Cyclagelosphaera & 12 & 7.9 & 259 & $\begin{array}{l}C_{N} \text { from published SEM images; } \Theta \text { estimated from lith } \\
\text { measurements at Sites } 1209,1403 \text { and published } \\
\text { coccosphere images. Geometry consistent with Pg } \\
\text { coccospheres }\end{array}$ \\
\hline \multirow[t]{5}{*}{ Coccolithales } & Chiasmolithus & 9 & 11.0 & 698 & Pg coccospheres \\
\hline & Coccolithus & 13 & $7.0-9.7$ & $180-478$ & $\begin{array}{l}C_{N} \text { from Pg coccospheres; } \Theta \text { change through Danian } \\
\text { estimated from lith measurements at Sites } 1209 \text { and } \\
1403 \text { using geometric relationship from Pg coccospheres }\end{array}$ \\
\hline & Cruciplacolithus (small) & 20 & $4.2-8.0$ & $39-268$ & $\begin{array}{l}C_{N} \text { and } \Theta \text { from Pg coccospheres and published } \\
\text { coccosphere images; } \Theta \text { change through Danian } \\
\text { estimated from lith measurements from Sites } 1209 \text { and } \\
1403 \text { using geometric relationship from } P g \text { coccospheres. }\end{array}$ \\
\hline & Cruciplacolithus (large) & 13 & $6.6-11.5$ & $151-796$ & $\begin{array}{l}\text { As for Cruciplacolithus (small), but considered to be } \\
\text { more like Chiasmolithus }\end{array}$ \\
\hline & Ericsonia & 13 & 7.6 & 226 & As for Coccolithus \\
\hline \multirow[t]{5}{*}{ Isochrysidales } & Neobiscutum & 9 & 3.0 & 14 & $\begin{array}{l}\text { Direct measurements of Danian coccospheres and } \\
\text { estimates of } \Theta \text { based on lith measurements from Sites } \\
1209,1403 \text { and } 1406 .\end{array}$ \\
\hline & Praeprinsius & 18 & $3.8-5.2$ & $29-74$ & $\begin{array}{l}\text { Direct measurements of Danian coccospheres and } \\
\text { estimates of } \Theta \text { change through Danian based on lith } \\
\text { measurements from Sites } 1209,1403 \text { and } 1406 .\end{array}$ \\
\hline & Futyania & 50 & 8.5 & 322 & Pg coccospheres and published coccosphere images \\
\hline & Prinsius & 20 & $4.0-5.5$ & $34-87$ & $\begin{array}{l}\text { Direct measurements of Danian coccospheres and } \\
\text { estimates of } \Theta \text { change through Danian based on lith } \\
\text { measurements from Sites } 1209,1403 \text { and } 1406 \text {. }\end{array}$ \\
\hline & Toweius & 7 & 4.7 & 31 & $\begin{array}{l}C_{N} \text { from } P g \text { coccospheres; } \Theta \text { estimated from lith } \\
\text { measurements from Sites } 1209 \text { and } 1403 \text { using } \\
\text { geometric relationship from } P g \text { coccospheres. }\end{array}$ \\
\hline Zygodiscales & Neochiastozygus & 32.5 & 16.5 & 2352 & Ref. 46 \\
\hline Discoasterales & $\begin{array}{l}\text { Fasciculithus, } \\
\text { Sphenolithus }\end{array}$ & 42 & 21.7 & 5350 & Ref. 46 \\
\hline Incertae & Biantholithus & 13 & 13.7 & 1337 & $\mathrm{Pg}$ coccospheres \\
\hline Non-nannofossil & Calcisphere fragments & 16 & 20.0 & 4189 & Pg coccospheres \\
\hline
\end{tabular}


772 Extended Data Table 2. Carbon isotope excursion events. Columns provide event 773 nomenclature, depth in core at Site 1209, age and estimated size of the CIE. Values in 774 parentheses show the range of CIEs from the literature cited and the value in bold is the size 775 of CIE used in Figure 2. Event nomenclature follows references given in the Methods, depths 776 (rmcd - revised metres composite depth) use the revised depth splice of ref 33 and the ages 777 use the age model from ref 32 .

778

\begin{tabular}{|c|c|c|c|c|}
\hline Event & $\begin{array}{c}\text { Depth } \\
\text { (rmcd, splice) }\end{array}$ & $\begin{array}{c}\text { Age } \\
\text { (Myrs ago) }\end{array}$ & $\begin{array}{c}\text { Size of CIE } \\
(\%)\end{array}$ & References \\
\hline 12 & 210.02 & 53.55 & $\begin{array}{c}0.48 \\
{[0.1-0.6]}\end{array}$ & $21,65,66$ \\
\hline 11 & 210.60 & 53.67 & $\begin{array}{c}\mathbf{0 . 6 5} \\
{[0.5-0.7]}\end{array}$ & $21,65,66$ \\
\hline $\mathrm{H} 2$ & 211.83 & 53.95 & $\begin{array}{c}0.49 \\
{[0.2-0.6]}\end{array}$ & $21,51,65,66$ \\
\hline $\mathrm{H} 1$ & 212.48 & 54.05 & $\begin{array}{c}1.5 \\
{[0.6-1.6]}\end{array}$ & $21,51,65-67$. \\
\hline PETM & 218.00 & 55.93 & $\begin{array}{c}3.0 \\
{[2.4-3]}\end{array}$ & 68,69 \\
\hline PCIM & 229.94 & 58.10 & 1.0 & 48,49 \\
\hline ELPE & 235.00 & 59.27 & 0.75 & $48,49,72$ \\
\hline LDE & 247.69 & 62.03 & 1.0 & $48,71-76$ \\
\hline L C29n & 258.83 & 65.34 & 0.7 & 50,77 \\
\hline Dan C2 & 260.11 & 65.71 & 1.3 & $50,77,78$ \\
\hline
\end{tabular}

